\title{
CHARACTERISTICS OF TREATMENT AND OUTCOME IN ELDERLY PATIENTS WITH BRAIN GLIOBLASTOMA: A RETROSPECTIVE ANALYSIS OF CASE SERIES
}

\author{
Mauro Dobran ${ }^{1}$, Davide Nasi ${ }^{1}$, Martina Della Costanza ${ }^{1}$, Maurizio Gladi ${ }^{1}$, \\ Maurizio Iacoangeli ${ }^{1}$, Krešimir Rotim ${ }^{2}$ and Bruno Splavski ${ }^{2}$
}

${ }^{1}$ Department of Neurosurgery Università Politecnica delle Marche, Ospedali Riuniti di Ancona, Ancona, Italy; ${ }^{2}$ Department of Neurosurgery, Sestre milosrdnice University Hospital Centre, Zagreb, Croatia

\begin{abstract}
SUMMARY - Treatment modalities affecting quality of life and survival in elderly brain glioblastoma patients are not well defined. A single-institution data were analyzed during a 3-year period to disclose prognostic difference in management related to age. Karnofsky Performance Scale (KPS), overall survival (OS), and adjuvant therapy were evaluated. The case group comprised of elderly patients ( $>75$ years), while the control group included those of younger age ( $<65$ years). The investigated variables were correlated between the groups. Twenty elderly patients and a corresponding number of younger ones were analyzed. Preoperative KPS $>70$ indicated longer overall survival. Statistically significant correlation was recorded in both the control $(\mathrm{p}=0.036)$ and case $(\mathrm{p}=0.0053)$ groups. Lower postoperative KPS was significantly correlated with shorter OS in elderly patients $(\mathrm{p}=0.023)$. The correlation between the extent of tumor resection and OS was statistically significant in younger patients only ( $\mathrm{p}=0.04)$. Overall survival was significantly shorter in elderly patients regardless of the extent of tumor resection $(\mathrm{p}=0.0057)$. Adjuvant therapy was significantly associated with longer OS in both the case $(\mathrm{p}=0.032)$ and control $(\mathrm{p}=0.013)$ groups. Elderly population is a more endangered group of surgical brain glioblastoma patients having lower quality of life and shorter overall survival. The management protocol should be personalized for each individual case in this age group of patients to reduce postoperative complications and grant a satisfactory quality of life.
\end{abstract}

Key words: Elderly patients; Glioblastoma; Management outcome; Prognosis; Treatment modalities

\section{Introduction}

Glioblastoma is the most common primary malignant intracranial tumor with the incidence of 4-5/100,000 per year ${ }^{1,2}$. Despite advances in molecular diagnostics and therapy, overall survival (OS) of glioblastoma patients is poor, ranging from 8 to 11 months in many studies for most patients ${ }^{3,4}$. In elderly patients, standard treatment (surgery-radiotherapy-chemotherapy) is not defined yet and there is little agreement

Correspondence to: Mauro Dobran, MD, Department of Neurosurgery, Università Politecnica delle Marche, Ospedali Riuniti di Ancona, Via Conca \#71, I-60020, Torrette di Ancona, Italy E-mail: dobran@libero.it

Received January 21, 2019, accepted March 14, 2019 about the real benefit of specific treatment modalities affecting the quality of life $\mathrm{e}^{5,6}$.

Surgery is the first step of treatment of glioblasto$\mathrm{ma}$ in resectable locations in younger patients, but many elderly patients have a poor clinical outcome without a chance of completing the standard protocol of therapy. Moreover, the selection of patients who may benefit from standard treatment is difficult and no validated stratification tools are currently available. Nevertheless, it appears that elderly patients benefit less from surgery regarding survival and quality of life.

For this purpose, the authors analyzed their institution experience in respect to treatment modalities applied, management outcomes and OS in a series of brain glioblastoma surgical patients aged over 75 years in comparison to younger ones. 


\section{Patients and Methods}

We compared clinical and radiological data in 20 elderly patients ( $\geq 75$ years) and 20 younger ones $(\leq 65$ years) affected by cerebral glioblastoma and operated on at the Department of Neurosurgery, University of Ancona, from January 2012 until January 2015. The groups were matched for clinical variables, surgical outcomes, adjuvant therapy, Karnofsky Performance Scale (KPS) and OS.

All procedures performed in the study were in accordance with ethical standards of the institutional and/or national research committee and the $1964 \mathrm{Hel}-$ sinki Declaration and its later amendments or comparable ethical standards. An informed consent was obtained from all participants included in the study.

Surgery was indicated for treatment of space-occupying and/or symptomatic tumor lesions. All patients underwent preoperative magnetic resonance imaging (MRI) study and brain computed tomography (CT) scan, which was repeated 24/48 hours after surgery and at 3-6-12-month follow-ups. Baseline demographic and medical data including patient gender and age at admission, major presenting symptoms, tumor location and grade of resection were evaluated. Histopathologic grading according to the World Health Organization (WHO) criteria and molecular markers (MGMT and IDH1/2) were determined from histopathological reports. Surgical resection was categorized as biopsy, subtotal tumor resection (STR) or total tumor macroscopic resection (TTR). Patients with no history of epileptic seizures were treated with prophylactic anticonvulsant therapy preoperatively (levetiracetam $500 \mathrm{mg}$ twice a day for 2-4 weeks). In case of epileptic seizures, therapy was prolonged. To assess the quality of life, KPS was evaluated before surgery, 48 hours after surgery and at 2-month follow-up. Radiotherapy and chemotherapy adjuvant treatment, progression free survival (PFS) and OS were recorded and analyzed.

The PFS was defined as the interval between initial surgery and radiological progression of disease. The OS was defined as the interval between initial surgery and the date of death. The radiotherapy treatment consisted of conventional radiation therapy defined as 5060 Gy delivered in 20-30 fractions. Chemotherapy protocol included temozolomide, which was administered at a dose of $75 \mathrm{mg} / \mathrm{m}^{2}$ daily, followed by six cycles of $200 \mathrm{mg} / \mathrm{m}^{2}$ for 5 days every 4 weeks. All patients were screened for IDH1/2 mutations by direct sequencing, and for promoter status of MGMT gene by the methylation-specific polymerase chain reaction.

All data of elderly patients comprising the case group were compared with data from the control group of patients aged $<65$. Kaplan-Meyer survival curves and univariate logistic regression were used on statistical analysis. The variables with $\mathrm{p}<0.05$ were considered statistically significant. The software used for analysis was the SPSS Version 19 (IBM, Armonk, New York, USA).

\section{Results}

From January 2012 until January 2015, we operated on 20 patients aged $>75$ affected by cerebral glioblastoma (case group) and 20 patients younger than 65 (control group). Baseline characteristics of the entire sample are summarized in Table 1. Univariate logistic regression of preoperative and postoperative variables tested for the entire sample are depicted in Table 2. Univariate logistic regression of preoperative and postoperative variables tested for the case and control groups separately are shown in Table 3.

In the case group consisting of 20 patients, the improvement on KPS 48 hours after surgery was by 10 points in four patients, 20 points in four patients and 30 points in one patient, while KPS was unchanged in seven patients. The KPS values worsened in four out of 20 patients. One patient died one week after surgery due to cardiovascular failure. At 2-month follow-up, systemic complications occurred in three out of $19 \mathrm{pa}^{-}$ tients and KPS worsened in ten (52.6\%) patients.

In the control group, median preoperative KPS was 65.2 , postoperative 72.5 , and 70.5 at 2 -month followup. No systemic postoperative complications were recorded.

In 12 elderly patients having undergone TTR followed by oncologic standard treatment, the OS was 7.8 months versus 6.0 months only in eight patients having undergone STR. In the control group, median survival was 12.0 months in TTR patients and 5.9 months in STR patients. No mortality was documented in the control group.

A preoperative KPS $>70$ was associated with longer OS in both younger $(\mathrm{p}=0.036)$ and elderly $(\mathrm{p}=$ 0.0053 ) patients, which was statistically significant. 
Table 1. Baseline characteristics of the entire study sample

\begin{tabular}{|c|c|c|c|}
\hline $\begin{array}{l}\text { Patient } \\
\text { characteristic }\end{array}$ & $\begin{array}{l}\text { Case } \\
\text { group } \\
\text { (elderly) } \\
\mathrm{n}(\%)\end{array}$ & $\begin{array}{l}\text { Control } \\
\text { group } \\
\text { (younger) } \\
\mathrm{n}(\%)\end{array}$ & $\mathrm{p}$ value \\
\hline $\begin{array}{l}\text { Total number } \\
\text { of patients }\end{array}$ & 20 & 20 & \\
\hline $\begin{array}{l}\text { Age (years) } \\
(\text { mean } \pm \mathrm{SD}) \\
\text { range }\end{array}$ & $\begin{array}{l}78( \pm 3.15) \\
75-85\end{array}$ & $\begin{array}{l}58.25( \pm 3.71) \\
39-65\end{array}$ & / \\
\hline $\begin{array}{l}\text { Gender } \\
\text { Male } \\
\text { Female } \\
\end{array}$ & $\begin{array}{l}8(40 \%) \\
12(60 \%)\end{array}$ & $\begin{array}{l}9(45 \%) \\
(55 \%)\end{array}$ & $>0.05$ \\
\hline $\begin{array}{l}\text { Tumor location } \\
\text { Frontal } \\
\text { Parietal } \\
\text { Temporal } \\
\text { Occipital }\end{array}$ & $\begin{array}{l}5(25 \%) \\
7(35 \%) \\
5(25 \%) \\
3(15 \%)\end{array}$ & $\begin{array}{l}7(35 \%) \\
5(25 \%) \\
5(25 \%) \\
3(15 \%)\end{array}$ & $>0.05$ \\
\hline $\begin{array}{l}\text { Preoperative KPS } \\
\quad(\text { mean } \pm \mathrm{SD}) \\
\geq 70 \\
<70\end{array}$ & $\begin{array}{l}63( \pm 8.87) \\
10(50 \%) \\
10(50 \%)\end{array}$ & $\begin{array}{l}65.23( \pm 7.57) \\
9(45 \%) \\
11(55 \%)\end{array}$ & $>0.05$ \\
\hline $\begin{array}{l}\text { Extent of resection } \\
\text { TTR } \\
\text { STR }\end{array}$ & $\begin{array}{l}12(60 \%) \\
8(40 \%)\end{array}$ & $\begin{array}{l}13(65 \%) \\
7(35 \%)\end{array}$ & $>0.05$ \\
\hline $\begin{array}{l}\text { Adjuvant therapy } \\
\text { RT + ChT } \\
\text { RT } \\
\text { None }\end{array}$ & $\begin{array}{l}10(50 \%) \\
2(10 \%) \\
8(40 \%)\end{array}$ & $\begin{array}{l}15(75 \%) \\
4(20 \%) \\
1(5 \%) \\
\end{array}$ & $>0.05$ \\
\hline $\begin{array}{l}\text { IDH1/2 mutation } \\
\text { Yes } \\
\text { No }\end{array}$ & $\begin{array}{l}0 \\
20(100 \%)\end{array}$ & $\begin{array}{l}1(5 \%) \\
19(95 \%)\end{array}$ & $>0.05$ \\
\hline $\begin{array}{l}\text { MGMT promoter } \\
\text { Methylated } \\
\text { Unmethylated }\end{array}$ & $\begin{array}{l}7(35 \%) \\
13(65 \%)\end{array}$ & $\begin{array}{l}12(60 \%) \\
8(40 \%)\end{array}$ & 0.19 \\
\hline
\end{tabular}

$\mathrm{SD}=$ standard deviation; KPS = Karnofsky Performance Scale; TTR = total tumor resection; STR = subtotal tumor resection; RT $=$ radiotherapy; $\mathrm{ChT}=$ chemotherapy

The correlation between the extent of tumor resection and OS was statistically significant in the control group of younger patients only ( $\mathrm{p}=0.04)$ (Fig. $1 \mathrm{AB}$ ). The correlation between postoperative KPS and OS was statistically significant in the case group of elderly patients only ( $\mathrm{p}=0.023)$ (Fig. 2AB).
Table 2. Univariate logistic regression of preoperative and postoperative variables in the entire study sample

\begin{tabular}{|c|c|c|c|c|}
\hline \multirow[t]{2}{*}{ Variable } & \multicolumn{4}{|c|}{ Overall (40 patients) } \\
\hline & $\begin{array}{l}\text { OS } \\
\text { (months) }\end{array}$ & HR & $95 \%$ CI & $\mathrm{p}$ value \\
\hline \multicolumn{5}{|l|}{ Age (years) } \\
\hline$>75$ & 7 & & & \\
\hline \multirow[t]{2}{*}{$<65$} & 12 & & & \\
\hline & I & 2.51 & 1.48 to 10.3 & 0.0056 \\
\hline \multicolumn{5}{|l|}{$\begin{array}{l}\text { Preoperative } \\
\text { KPS }\end{array}$} \\
\hline$\geq 70$ & 11 & & & \\
\hline \multirow[t]{2}{*}{$<70$} & 7 & & & \\
\hline & / & 0.39 & 0.09 to 0.66 & 0.0052 \\
\hline \multicolumn{5}{|l|}{$\begin{array}{l}\text { Extent } \\
\text { of resection }\end{array}$} \\
\hline TTR & 9 & & & \\
\hline \multirow[t]{2}{*}{ STR } & 6 & & & \\
\hline & 1 & 0.47 & 0.11 to 0.92 & 0.034 \\
\hline \multicolumn{5}{|l|}{$\begin{array}{l}\text { Postoperative } \\
\text { KPS }\end{array}$} \\
\hline$\geq 70$ & 8.5 & & & \\
\hline \multirow[t]{2}{*}{$<70$} & 7 & & & \\
\hline & & 0.58 & 0.16 to 1.3 & 0.14 \\
\hline \multicolumn{5}{|l|}{$\begin{array}{l}\text { Adjuvant } \\
\text { therapy }\end{array}$} \\
\hline $\mathrm{RT}+\mathrm{ChT}$ & 10 & & & \\
\hline RT & 7 & & & \\
\hline \multirow[t]{2}{*}{ None } & 3 & & & \\
\hline & & 0.49 & 0.08 to 0.93 & 0.0001 \\
\hline \multicolumn{5}{|l|}{$\begin{array}{l}\text { MGMT } \\
\text { promoter }\end{array}$} \\
\hline Methylated & 11 & & & \\
\hline \multirow[t]{2}{*}{ Unmethylated } & 7 & & & \\
\hline & & 0.39 & 0.09 to 0.66 & 0.0052 \\
\hline
\end{tabular}

OS = overall survival; $\mathrm{HR}=$ hazard ratio $\mathrm{CI}=$ confidence interval; KPS = Karnofsky Performance Scale; TTR = total tumor resection; $\mathrm{STR}=$ subtotal tumor resection; $\mathrm{RT}=$ radiotherapy; $\mathrm{ChT}=$ chemotherapy

Adjuvant therapy was associated with longer OS in both groups of patients (Table 2). The OS was 7.0 months in the case group of elderly patients and 12.0 months in the control group of younger patients, yielding a statistically significant difference $(\mathrm{p}=0.0057)$. 
Table 3. Univariate logistic regression of preoperative and postoperative variables in case group (elderly, age $>75$ ) and control group (younger, age <65)

\begin{tabular}{|c|c|c|c|c|c|c|c|c|}
\hline \multirow[t]{2}{*}{ Variable } & \multicolumn{3}{|c|}{$\begin{array}{l}\text { Case group (elderly) } \\
\text { (20 patients) }\end{array}$} & \multirow[b]{2}{*}{$\mathrm{p}$} & \multicolumn{4}{|c|}{$\begin{array}{l}\text { Control group (younger) } \\
\text { (20 patients) }\end{array}$} \\
\hline & $\begin{array}{l}\text { OS } \\
\text { (months) }\end{array}$ & HR & $95 \% \mathrm{CI}$ & & $\begin{array}{l}\text { OS } \\
\text { (months) }\end{array}$ & HR & $95 \% \mathrm{CI}$ & $\mathrm{p}$ \\
\hline $\begin{array}{l}\text { Preoperative KPS } \\
\geq 70 \\
<70\end{array}$ & $\begin{array}{l}9 \\
3\end{array}$ & 0.35 & 0.059 to 0.77 & 0.019 & $\begin{array}{l}12 \\
7.5 \\
/\end{array}$ & 0.39 & 0.038 to 0.95 & 0.043 \\
\hline $\begin{array}{l}\text { Extent of resection } \\
\text { TTR } \\
\text { STR }\end{array}$ & $\begin{array}{l}7.8 \\
6 \\
1\end{array}$ & 0.77 & 0.22 to 2.31 & 0.57 & $\begin{array}{l}12 \\
5.9\end{array}$ & 0.27 & 0.08 to 0.75 & 0.02 \\
\hline $\begin{array}{l}\text { Postoperative KPS } \\
\geq 70 \\
<70\end{array}$ & $\begin{array}{l}8.5 \\
4\end{array}$ & 0.037 & 0.05 to 0.81 & 0.02 & $\begin{array}{l}11 \\
8.3\end{array}$ & 0.42 & 0.02 to 1.53 & 0.42 \\
\hline $\begin{array}{l}\text { Adjuvant therapy } \\
\text { RT + ChT } \\
\text { RT } \\
\text { None }\end{array}$ & $\begin{array}{l}10 \\
8 \\
2\end{array}$ & 0.037 & 0.05 to 0.81 & 0.005 & & $\begin{array}{l}12 \\
9 \\
3\end{array}$ & & 0.0132 \\
\hline $\begin{array}{l}\text { MGMT promoter } \\
\text { Methylated } \\
\text { Unmethylated }\end{array}$ & $\begin{array}{l}10 \\
3\end{array}$ & 0.51 & 0.12 to 0.98 & 0.0001 & $\begin{array}{l}12.5 \\
5\end{array}$ & 0.39 & 0.18 to 0.85 & 0.0001 \\
\hline
\end{tabular}

OS = overall survival; $\mathrm{HR}$ = hazard ratio; $\mathrm{CI}$ = confidence interval; KPS = Karnofsky Performance Scale; TTR = total tumor resection; STR = subtotal tumor resection; $\mathrm{RT}=$ radiotherapy; $\mathrm{ChT}=$ chemotherapy

Considering IDH1/2 mutations, they were detected in only one (5\%) patient from the control group, whereas none of the case group patients presented with IDH1/2 mutations. Due to the almost complete absence of IDH1/2 mutations in our sample, statistical analysis of correlation between these molecular markers and OS was not possible.

Methylation of the MGMT gene promoter was found in $12(60 \%)$ patients from the control group and seven $(35 \%)$ patients from the case group. On univariate logistic regression, the $\mathrm{OS}$ was significantly longer in patients with methylation of the MGMT promoter in both groups $(p=0.0052)$ (Table 2$)$.

\section{Discussion}

Glioblastoma (WHO grade IV) is the most common malignant primary brain tumor in adults ${ }^{2,7}$. Stan- dard treatment for patients with glioblastoma is surgical resection with adjuvant therapy (radiotherapy and chemotherapy). Due to the presence of comorbidities in elderly patients, the benefit from standard treatment has been questioned ${ }^{5,6,8}$. Accordingly, many studies have shown an increased postoperative mortality and morbidity in elderly patients ${ }^{9}$. However, the treatment of glioblastoma in elderly patients has become an everyday issue due to prolonged life expectation in the general population.

In this study, the modality and outcomes of treatment of 20 glioblastoma surgical patients aged $>75$ were evaluated and compared to a younger group of patients ( $\leq 65$ years).

As previously reported in the literature, a statistically significant correlation between preoperative KPS and the length of OS was established regardless of pa- 

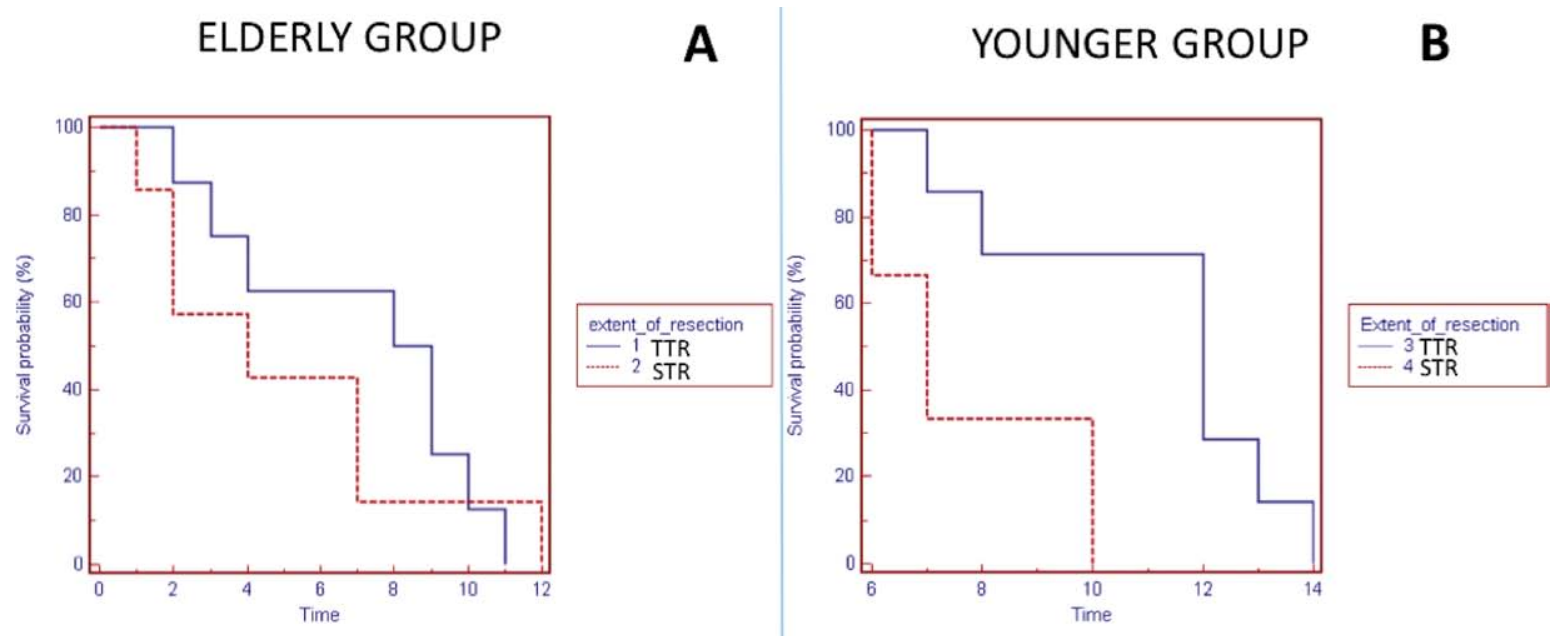

Fig. 1. Kaplan-Meier overall survival (OS) curves demonstrating significantly improved survival in patients having undergone total tumor resection (TTR). Improved survival was only observed in younger patients ( $B$, control group) with subtotal tumor resection (STR) in contrast to elderly ones ( $A$, case group).
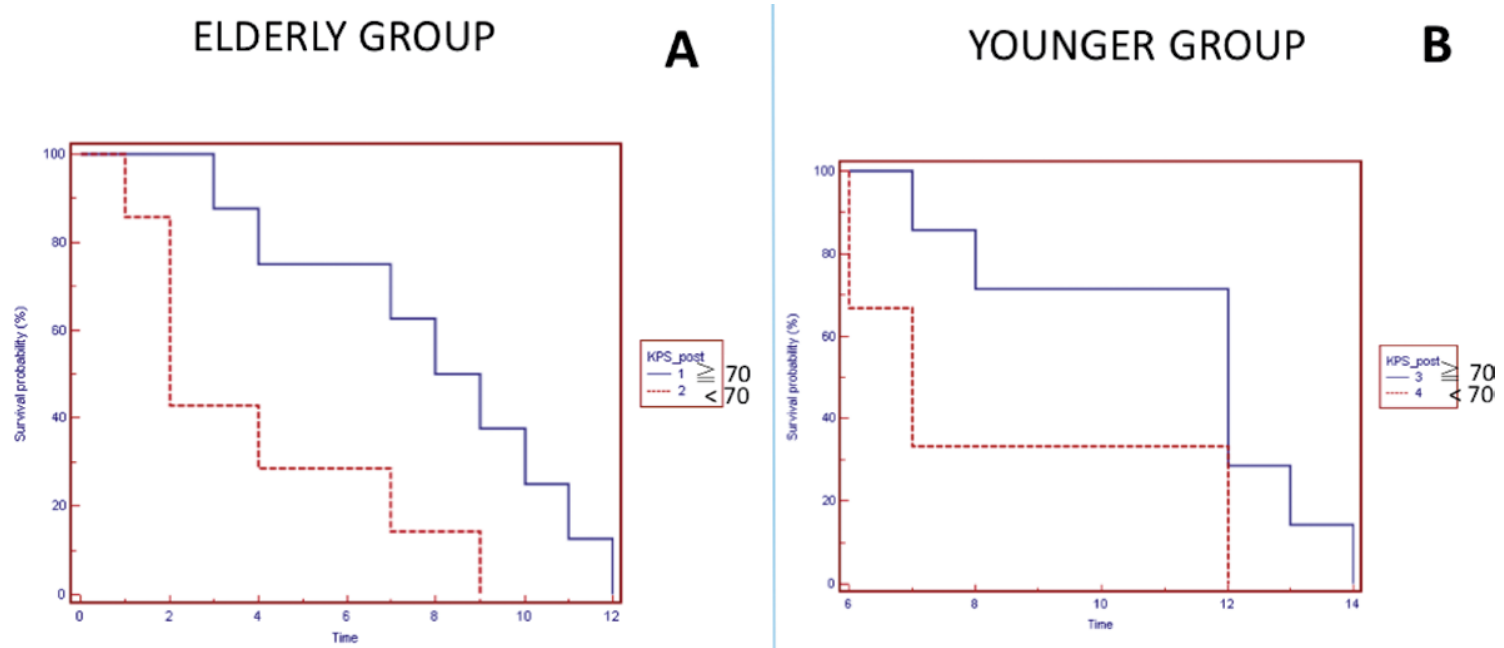

Fig. 2. Kaplan-Meier overall survival (OS) curves demonstrating significantly improved survival in patients with postoperative Karnofsky Performance Scale (KPS) > 70 from both groups. Significantly improved survival was observed only in elderly patients ( $A$, case group) with postoperative KPS $<70$ in contrast to the younger ones ( $B$, control group).

tient age ${ }^{10}$. In our series, KPS values at 2 -month follow-up were lower than the preoperative ones in more than half (10/19) of elderly patients. On the contrary, KPS values at 2-month follow-up obtained for younger patients were higher than the preoperative ones.

Data analysis showed that postoperative KPS values were significantly correlated to $\mathrm{OS}$ in the case group of elderly patients only ( $\mathrm{p}=0.023$ ), where postoperative neurological worsening appeared to be criti- cal. In this group, new deficits were associated with poor quality of life and decreased survival. For these reasons, standard protocols of adjuvant radiotherapy and/or chemotherapy are often denied in such patients ${ }^{10-14}$.

In one elderly patient from our series, glioblastoma was asymptomatic and it was diagnosed after a polytrauma with vertebral fracture treated with screws and rods ${ }^{15,16}$. This patient developed deep vertebral infec- 
tion four months after surgery during radiotherapy and chemotherapy treatment, which was cured with broad-spectrum antibiotics eliminating the need of spinal instrumentation removal ${ }^{17-19}$.

Several relevant studies demonstrated that advanced age may be associated with poor prognosis in glioblastoma patients ${ }^{3,420-22}$. The same was also observed in our series, where the group of elderly patients had significantly shorter OS when compared to the younger ones $(\mathrm{p}=0.0057)$.

Although some authors stress the importance of the extent of resection regardless of age $\mathrm{e}^{12}$,we found the extent of tumor resection (total or subtotal) to be significantly correlated with OS in younger patients only $(\mathrm{p}=0.04)$, whereas in elderly patients this correlation was not statistically significant. Accordingly, it seems that the extent of tumor resection is not an essential prognostic predictor in elderly patients. Since the presence of comorbidities and preservation of good clinical status are more relevant for elderly patients, the extent of tumor resection seems not to be a determining factor influencing OS. Hence, aggressive surgical treatment in elderly patients to achieve TTR is not always proposed, since it bears a high risk of neurological deterioration and/or complications, which in turn may preclude adjuvant therapy and early mobilization, leading to poor outcome. Accordingly, our data suggested that elderly patients who were able to complete standard treatment protocol (surgery, chemotherapy and radiotherapy) showed the best OS. In the light of this finding, minimally invasive treatment options may decrease the post-surgical complication rates $^{23}$, and early rehabilitation may help maintain intact neurological status in elderly patients ${ }^{24}$.

Remembering our results, adjuvant therapy was associated with longer OS in elderly patients, which is consistent with other reports stressing that bimodal adjuvant treatment improves survival in the aging ${ }^{25}$.

Nowadays, characterization of molecular biomarkers represents an integral part of modern neuro-oncology and can help in the management of glioblastoma patients too. Literature data indicate that IDH mutations, which are associated with secondary glioblasto$\mathrm{ma}$, are a consistent prognostic marker in low-grade and high-grade gliomas ${ }^{26-28}$. However, due to the almost complete absence of IDH1/2 mutations in our sample, statistical analysis of the correlation between these molecular markers and survival was not possible.
Another molecular marker investigated in this study was promoter status of the MGMT gene. Our study confirmed that OS was significantly longer in patients with methylation of the MGMT promoter in both groups of patients regardless of their age. Several clinical studies have shown that methylation of the MGMT promoter is a strong and independent prognostic factor associated with prolonged PFS and $\mathrm{OS}^{27,29-32}$. However, this observation was not previously reported for patients over 75 years of age, which may be an original contribution of our study.

In conclusion, remembering the limited number of patients in our series, our results suggest that surgery can be successfully performed in selected glioblastoma patients in spite of their age, in respect to quality of life and OS. However, elderly population is a more endangered group of surgical brain glioblastoma patients having lower quality of life and shorter OS. Careful preoperative stratification, tailored surgical approach and balanced adjuvant therapy are beneficial for recovery and prognosis. Therefore, the management protocol should be personalized for each individual case in this age group of patients to reduce postoperative complications and grant a satisfactory quality of life.

\section{References}

1. Dolecek TA, Propp JM, Stroup NE, Kruchko C. CBTRUS statistical report: Primary brain and central nervous system tumors diagnosed in the United States in 2005-2009. Neuro Oncol. 2012;14(Suppl 5):v1-49. doi: 10.1093/neuonc/nos218.

2. Zhang AS, Ostrom QT, Kruchko C, Rogers L, Peereboom DM, Barnholtz-Sloan JS. Complete prevalence of malignant primary brain tumors registry data in the United States compared with other common cancers, 2010. Neuro Oncol. 2017; 19(5):726-35. doi: 10.1093/neuonc/now252.

3. Álvarez de Eulate-Beramendi S, Álvarez-Vega MA, Balbin M, Sanchez-Pitiot A, Vallina-Alvarez A, Martino-González J. Prognostic factors and survival study in high-grade glioma in the elderly. Br J Neurosurg. 2016;30(3):330-6. doi: 10.3109/02688697.2016.1139049.

4. Babu R, Komisarow JM, Agarwal VJ, Rahimpour S, Iyer A, Britt D, et al. Glioblastoma in the elderly: the effect of aggressive and modern therapies on survival. J Neurosurg. 2016; 124(4):998-1007. doi: 10.3171/2015.4.JNS142200.

5. Bauman GS, Gaspar LE, Fisher BJ, Halperin EC, Macdonald DR, Cairncross JG. A prospective study of short-course radiotherapy in poor prognosis glioblastoma multiforme. Int J Radiat Oncol Biol Phys. 1994;29(4):835-9.

6. Marijnen CA, van den Berg SM, van Duinen SG, Voormolen $\mathrm{JH}$, Noordijk EM. Radiotherapy is effective in patients with 
glioblastoma multiforme with a limited prognosis and in $\mathrm{pa}^{-}$ tients above 70 years of age: a retrospective single institution analysis. Radiother Oncol. 2005;75(2):210-6. doi: 10.1016/j. radonc.2005.03.004.

7. Ostrom QT, Gittleman H, Farah P, Ondracek A, Chen Y, Wolinsky Y, et al. CBTRUS statistical report: Primary brain and central nervous system tumors diagnosed in the United States in 2006-2010. Neuro Oncol. 2013;15(Suppl 2):1-56. doi: 10.1093/neuonc/not151.

8. Morgan ER, Norman A, Laing K, Seal MD. Treatment and outcomes for glioblastoma in elderly compared with non-elderly patients: a population-based study. Curr Oncol. 2017;24 (2):e92-e98. doi: 10.3747/co.24.3424.

9. Brell M, Ibáñez J, Caral L, Ferrer E. Factors influencing surgical complications of intra-axial brain tumours. Acta Neurochir. 2000;142(7):739-50.

10. Lorimer CF, Hanna C, Saran F, Chalmers A, Brock J. Challenges to treating older glioblastoma patients: the influence of clinical and tumour characteristics on survival outcomes. Clin Oncol. 2017;S0936-6555(17)30275-3.

doi: 10.1016/j.clon.2017.05.010.

11. Kumar N, Kumar P, Angurana SL, Khosla D, Kumar Mukherjee K, Aggarwal R, et al. Evaluation of outcome and prognostic factors in patients with glioblastoma multiforme: a single institution experience. J Neurosci Rural Pract. 2013;4(Suppl 1): S46-S55. doi: 10.4103/0976-3147.116455.

12. Oszvald A, Güresir E, Setzer M, Vatter H, Senft C, Seifert V, et al. Glioblastoma therapy in the elderly and the importance of the extent of resection regardless of age. J Neurosurg. 2012; 16(2):357-64. doi: 10.3171/2011.8.JNS102114.

13. Stark AM, van de Bergh J, Hedderich J, Mehdorn HM, Nabavi A. Glioblastoma: clinical characteristics, prognostic factors and survival in 492 patients. Clin Neurol Neurosurg. 2012; 114(7):840-5. doi: 10.1016/j.clineuro.2012.01.026.

14. Tanaka S, Meyer FB, Buckner JC, Uhm JH, Yan ES, Parney IF. Presentation, management, and outcome of newly diagnosed glioblastoma in elderly patients. J Neurosurg. 2013;118(4): 786-98. doi: 10.3171/2012.10.JNS112268.

15. Dobran M, Iacoangeli M, Di Somma LGM, Di Rienzo A, Colasanti R, Nocchi N, et al. Neurological outcome in a series of 58 patients operated for traumatic thoracolumbar spinal cord injuries. Surg Neurol Int. 2014;5(Suppl 7):S329-S332. doi: 10.4103/2152-7806.139645.

16. Dobran M, Nasi D, Brunozzi D, Di Somma LGM, Gladi M, Iacoangeli $\mathrm{M}$, et al. Treatment of unstable thoracolumbar junction burst fractures: short-segment pedicle fixation with inclusion of fracture level versus long-term instrumentation. Acta Neurochir (Wien). 2016;158(10):1883-9. doi: 10.1007/s00701-016-2907-0.

17. Dobran M, Mancini F, Nasi D, Scerrati M. A case of deep infection after instrumentation in dorsal spinal surgery: the management with antibiotics and negative wound pressure without removal of fixation. BMJ Case Rep. 2017;pii: bcr-2017-220792. doi: 10.1136/bcr-2017-220792.
18. Dobran M, Marini A, Nasi D, Gladi M, Liverotti V, Della Costanza M, et al. Risk factors of surgical site infections in instrumented spine surgery. Surg Neurol Int. 2017;8:212. doi: 10.4103/sni.sni 22217.

19. Dobran M, Marini A, Gladi M, Nasi D, Colasanti R, Benigni $\mathrm{R}$, et al. Deep spinal infection in instrumented spinal surgery: diagnostic factors and therapy. G Chir. 2017;38(3):124-9. doi: 10.11138/gchir/2017.38.3.124.

20. Chaichana KL, Chaichana KK, Olivi A, Weingart JD, Bennett $\mathrm{R}$, Brem $\mathrm{H}$, et al. Surgical outcomes for older patients with glioblastoma multiforme: preoperative factors associated with decreased survival. Clinical article. J Neurosurg. 2011;114(3): 587-94. doi: 10.3171/2010.8.JNS1081.

21. Kuhnt D, Becker A, Ganslandt O, Bauer M, Buchfelder M, Nimsky C. Correlation of the extent of tumor volume resection and patient survival in surgery of glioblastoma multiforme with high-field intraoperative MRI guidance. Neuro Oncol. 2011; 13(12):1339-48. doi: 10.1093/neuonc/nor133.

22. Noorbakhsh A, Tang JA, Marcus LP, McCutcheon B, Gonda $\mathrm{DD}$, Schallhorn CS, et al. Gross-total resection outcomes in an elderly population with glioblastoma: a SEER-based analysis. J Neurosurg. 2014;120(1):31-9. doi: 10.3171/2013.9.JNS13877.

23. Iacoangeli M, Nocchi N, Nasi D, Di Rienzo A, Dobran M, Gladi M, et al. Minimally invasive supraorbital key-hole approach for the treatment of anterior cranial fossa meningiomas. Neurol Med Chir. 2016;56(4):180-5. doi: 10.2176/nmc. oa.2015-0242.

24. Morreale M, Marchione P, Pili A, Lauta A, Castiglia SF, Spallone A, et al. Early versus delayed rehabilitation treatment in hemiplegic patients with ischemic stroke: proprioceptive or cognitive approach? Eur J Phys Rehabil Med. 2016;52(1):81-9.

25. Konglund A, Helseth R, Lund-Johansen M, Helseth E, Meling TR. Surgery for high-grade gliomas in the aging. Acta Neurol Scand. 2013;128(3):185-93. doi: 10.1111/ane.12105.

26. Juratli TA, Kirsch M, Robel K, Soucek S, Geiger K, von Kummer R, et al. IDH mutations as an early and consistent marker in low-grade astrocytomas WHO grade II and their consecutive secondary high-grade gliomas. J Neurooncol. 2012;108 (3):403-10. doi: 10.1007/s11060-012-0844-1.

27. Juratli TA, Kirsch M, Geiger K, Klink B, Leipnitz E, Pinzer T, et al. The prognostic value of IDH mutations and MGMT promoter status in secondary high-grade gliomas. J Neurooncol. 2012;110(3):325-33. doi: 10.1007/s11060-012-0977-2.

28. Nobusawa S, Watanabe T, Kleihues P, Ohgaki H. IDH1 mutations as molecular signature and predictive factor of secondary glioblastomas. Clin Cancer Res. 2009;15(19):6002-7. doi: 10.1158/1078-0432.CCR-09-0715.

29. Dunn J, Baborie A, Alam F, Joyce K, Moxham M, Sibson R, et al. Extent of MGMT promoter methylation correlates with outcome in glioblastomas given temozolomide and radiotherapy. Br J Cancer. 2009;101(1):124-31. doi: 10.1038/sj. bjc. 6605127.

30. Rivera AL, Pelloski CE, Gilbert MR, Colman H, De La Cruz $\mathrm{C}$, Sulman EP, et al. MGMT promoter methylation is predic- 
tive of response to radiotherapy and prognostic in the absence of adjuvant alkylating chemotherapy for glioblastoma. Neuro Oncol. 2010;12(2):116-21.

doi: 10.1093/neuonc/nop020.

31. Brandes AA, Franceschi E, Tosoni A, Blatt V, Pession A, Tallini G, et al. MGMT promoter methylation status can predict the incidence and outcome of pseudoprogression after concomitant radiochemotherapy in newly diagnosed glioblastoma patients. J Clin Oncol. 2008;26(13):2192-97. doi: 10.1200/ JCO.2007.14.8163.

32. Stojsavljević M, Tasić G, Nikolić I, Repac N, Janićijević A, Sćepanović V, Rotim K, Rasulić L. Glioblastoma multiforme brain tumors located in the motor cortex - specific findings in comparison with low grade gliomas of the same localization: analysis of a sixty patient series. Acta Clin Croat. 2015;54 (4):402-8.

Sažetak

\title{
ZNAČAJKE LIJEČENJA I ISHODA U STARIJIH BOLESNIKA S GLIOBLASTOMOM MOZGA: RETROSPEKTIVNA ANALIZA NIZA SLUČAJEVA
}

\author{
M. Dobran, D. Nasi, M. Della Costanza, M. Gladi, M. Iacoangeli, K. Rotimi B. Splavski
}

Modaliteti liječenja od utjecaja na kvalitetu života i preživljavanje starijih bolesnika s glioblastomom još nisu jasno određeni. Kako bi se utvrdila prognostička razlika u primijenjenim oblicima liječenja u odnosu na dob bolesnika analizirani su podaci dobiveni trogodišnjim istraživanjem uzorka. Istraživani su sljedeći pokazatelji: Karnofskyjeva ljestvica (KPS), vrijeme ukupnog preživljavanja i primjena pomoćnog liječenja. Oglednu skupinu činili su stariji bolesnici ( $\geq 75$ godina), a kontrolnu skupinu oni mlađe dobi ( $\leq 65$ godina). Međusobno su uspoređivani istraživani parametri iz obje skupine bolesnika. Promatrano je 20 starijih i odgovarajući broj mlađih bolesnika. Prijeoperacijski KPS $>70$ upućivao je na dulje sveukupno preživljavanje. Statistički značajna korelacija zabilježena je u bolesnika kontrolne $(p=0,036)$ i ogledne $(p=0,0053)$ skupine. Niže poslijeoperacijske vrijednosti KPS bile su značajno povezane s kraćim vremenom preživljavanja u starijih bolesnika $(\mathrm{p}=0,023)$. Korelacija između opsežnosti tumorske resekcije i sveukupnog preživljavanja bila je statistički značajna samo u mlađoj dobnoj skupini $(\mathrm{p}=0,04)$. Vrijeme sveukupnog preživljavanja bilo je značajno kraće u starijih bolesnika neovisno o stupnju kirurške resekcije $(\mathrm{p}=0,0057)$. Primjena pomoćne terapije bila je značajno povezana s duljim sveukupnim preživljavanjem u oglednoj $(\mathrm{p}=0,032)$ i kontrolnoj $(\mathrm{p}=0,013)$ skupini. $U$ zaključku, starija je populacija ugroženija skupina kirurških bolesnika s glioblastomom u kojih je smanjena kvaliteta života i skraćeno vrijeme sveukupnog preživljavanja. Stoga je potrebno protokol liječenja prilagoditi svakom pojedinom bolesniku iz ove dobne skupine kako bi se smanjio udio poslijeoperacijskih komplikacija i poboljšala kvaliteta života.

Ključne riječi: Glioblastom; Modaliteti liječenja; Prognoza; Stariji bolesnici; Uspješnost liječenja 